\title{
Shareholder Value Disclosure Practices In India: A Content Analysis
}

\author{
*Merugu Venugopal **Dr. M Ravindar Reddy \\ *Research Scholar, School of Management, NIT Warangal \\ ** Associate Professor, School of Management, NIT Warangal
}

\begin{abstract}
Many organizations are accepting their goal as shareholder wealth maximization and working towards achieving it to attract long term capital. Financial statements may have become more transparent, but relevant information has become much more difficult to identify the information what shareholders are looking for. This paper addresses on the necessity of creating more transparent information through which companies would benefit in the long term. More than ever, it also raises a question if it is the time to take a step back and consider how an organization can more effectively communicate their business story to better convey shareholder value. The research methodology employed content analysis of annual performance reports for pharmaceutical industry in India. The results from the study reiterate on the importance of creating transparent information to its stakeholders for a long term profitability of the organization.
\end{abstract}

Keywords:Shareholder wealth maximization, Corporate governance, annual reports, vision and mission statements

\section{Introduction}

Asserting the confidence of shareholders and developing long term financial strategies has become the need of the hour for an organization to survive on a long run. Hence, value based management has gained lots of prominence and is a key measure in terms of assessing an organization's financial growth.In the modern economy, as organizations attempt to convey to their shareholders that they are a good investment opportunity by highlighting the real value of the organization through disclosure of pertinent information in the annual reports, mission and vision statements.

Organizations investing to ensure and enhance long-term shareholder value should distinguish themselves from those prioritizing short-term financial performance. In part by helping investors understand the fundamental implications of the regulatory instabilities confronted by organizations. The organizations reporting practices must impart shareholder confidence by providing the road map towards universally accepted goal of the corporation, i.e., shareholder wealth maximization, instead of gold old profit maximization as the corporate goal. Every activity towards the goal should be viewed as a value enhancing step. Disclosure or reporting practices (annual reports, mission and vision statements) will really improve the relationship of organizations with shareholders. Effective communication practices are essential and will improve the firm value(Groth, 1989).

Accountants are showcasing traditional methods like ROA, ROE, RONW, etc as accounting measures. However the modern value based measures such as economic value added(EVA), market value added (MVA), shareholder value added (SVA) and created shareholder value added (CSV) are the real value of an organization. But the accountants are in fact misinterpreting the shareholder value by considering the traditional measures (Stewart 2003).All the companies are advised to voluntarily disclose all the matters regarding their sustainability to enhance the accountability and transparency of their operations and help the investors in their proper valuation (Nobanee \& Ellili, 2015).

An organization considers good corporate governance as a prerequisite for meeting the objective of maximizing shareholders wealth in the current competitive market. Management responsibilities and practices exercised with the goal of providing strategic direction, ensuring that the goal is accomplished, ascertaining that the risks are managed appropriately and the resources are utilized effectively.

When an organization is committed to enhancing shareholder value, investors or shareholders do search for the answers to questions like the information provided or available to shareholders in the past and future commitments towards the long term shareholder value. Is the organization practicing and formulating strategy towards enhancing shareholder value or simply meeting the short term earnings?

From the existing literature, the discussion so far lead if the organization thinks about management or is it thinking towards maximizing shareholders value. The key focus of this paper is to examine if the organizations are looking towards the enhancing long term shareholder value or at least are verbally moving towards the goal.

DOI: $10.9790 / 5933-0802040108$

www.iosrjournals.org

$1 \mid$ Page 
Shareholder Value Disclosure Practices In India: A Content Analysis

The remainder of the paper is organized as follows. Initial sections examine the annual reports, vision and mission statements of organizations to see normative and factual arguments in support of the shareholder wealth maximization. Later sections take a look at corporate vision and mission statements.

\section{Literature review}

In the last few decades research on value based management, shareholder wealth maximization and corporate governance have gained increasing importance in financial growth of a company. Organizations now almost universally accept that the primary management task is value creation. Most directors and senior managers will be at ease with pushing the organization farther and faster in the creation of new methods to create more shareholder value(Lichtenstein \& Dade, 2007). The value-based management (VBM) enables the organizations towards increasing enterprise value and thereby increase in shareholder value (Beck \& Britzelmaier, 2013) (Rappaport, 2006).

This shareholder value approach was conceived by (Rappaport, 2006). His concept of 'creating shareholder value' supports the management's orientation towards maximizing the value of shareholder investments. Academicians and consulting firms across the globe have contended that there is a pervasive consensus that managers tend to adopt strategies that strive to maximize shareholder value and that doing so maximizes social welfare. (Loderer,et al.,2010)(Dockery \& Herbert, 2000). Alhazaimeh et al., (2014) emphasize that Jordanian companies in a small open economy adopt voluntary disclosure in annual reports on different types of information and they have a trend over time.

Hooghiemstra(2010) states thatletters to the shareholders are unaudited and no regulation to control the content of the letters. These are widely used in investors decision making. Chairman, Directors and CXO's use these letters to as a tool for attracting the shareholders. Leszczynska (2012)examined the content of sustainability reports prepared between 2005 and 2010 published by international companies and assessed the extent to which sustainability reporting can contribute to shareholder value. After an in-depth analysis of those reports, it was found there was important gaps in respect of inclusiveness, relevance of information, and neutrality. The sustainability reports are not providing the useful information what shareholders are looking for.

Indian organizations never gave much significance to maximizing shareholder value. Except for, a few select organizations never bothered to meet the changing value expectations of shareholders in the capital markets. Organizations either did not pay the dividend or paid at a level that was far lower than the opportunity cost of the investors. With no plan in place as to how to overcome the existing inefficiencies and exploit emerging opportunities, shareholders perceive that the value creation abilities of such firms were limited which in turn resulted in depressed prices of their shares. Financial reports, policies are key aspects of measures for a enhancing long term value. Few of key factors to consider from reports are corporate governance reports, messages from top management or board, vision and mission statements.

A recent study by (Kaur \& Narang, 2010)on the reporting practices of EVA (a measure of shareholder value) in the annual reports of India's largest 500 companies over a period from 2004 to 2008 in the Indian corporate sector reveals that just 37 companies ( 7.4 per cent of the sample) specifically mentioned the use of EVA metric in their public disclosures as financial measure and shareholder value. The study also identifies the EVA usage and disclosure choice in Indian companies is influenced by company's size, profitability, leverage, sales efficiency and residential status. Whereas, age and earnings potential of a company do not have a significant impact on EVA disclosures choice of a company.

Another important factor to consider is the mission statements. The content of mission statements has been a topic of interest in the past decades. This is because of the statement's specific content, rather than the mere existence of such a document, that makes a difference in firm performance(Bart \& Hupfer, 2004). Yet, some authors point out, further empirical evidence is needed to support the links between the content of mission statements and performance outcomes (Dermol, 2012). A Study by(Omran, Atrill, \& Pointon, 2002) mission significance found that there is no significant difference in shareholder returns between stakeholder-oriented and shareholder-oriented companies. They are of the opinion that it gives focus and encourages strategy implementation, improves organizational climate, internal or external communication, and improves management and leadership in a company

The global financial crisis has led to calls for greater corporate accountability and heightened controls over public corporations. While debate continues to rage in the academy and beyond over the promise and pitfalls of these measures. This Article observes that a similar paradigm is being advanced in the India and it moves beyond prior literature by articulating a statement of the corporate purpose that is consistent with this investor-driven enlightened shareholder value approach and presents normative arguments in its favor. The article also considers how enlightened shareholder value intersects with existing corporate governance(Ho, 2010). 
Effective communication practices will play a significant role in enabling shareholders in better decision making by providing less uncertainty of information(De Beer, 2014).Astudy by (Groth, 1989) offered a number of basic guidelines useful to managers to reduce the uncertainty of information and benefits of corporate communications to the shareholders.

The debate is now focused on the interplay between corporate governance and company success. They cross at a point where what matters is whether - and how - a company has created value for its owners.

\section{Research Methodology}

To the best knowledge of the researcher, there is no reported literature about the organization disclosure practices of shareholder value specifically in the pharmaceutical industry. All we are looking for are statements mentioning the importance of shareholders. Hence, this study is one of the first studies shed the light on Mission, vision and annual reports in Indian pharmaceutical industry.

The sample population of the study constitutes 77 Pharmaceutical companies in India listed on Bombay Stock Exchange (BSE). To examine the extent of shareholder value reporting practices among the selected companies, annual reports, mission and vision statements of each company were examined over a period of six years, from 2011 to 2016. These annual reports were downloaded from the Capitaline Plus database, companies' website and BSE.

\section{Theoretical Framework:}

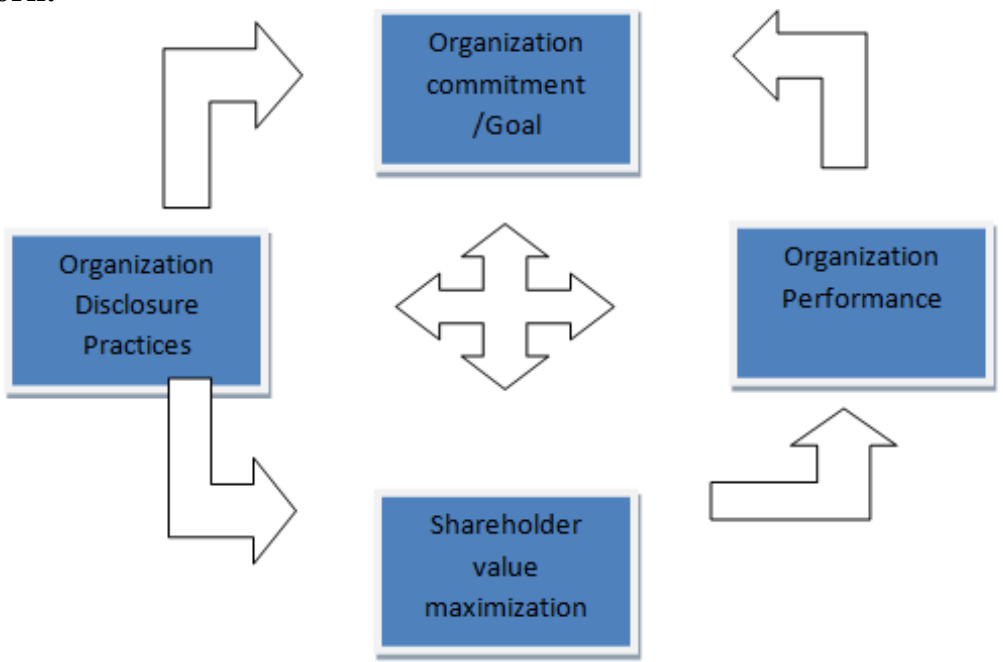

Figure-1: Relationship between the antecedents of shareholder wealth maximization

The conceptual framework in above figure illustrates how organizational commitment or goal and disclosure practices are towards wealth maximization of shareholders. Superior performance and long term shareholder value are achieved through aligning the organization's mission, goals, good governance and management commitment towards it. The stakeholders of the organization have to support in each step towards achieving the vision through achieving their desired ends. Managers should keep the shareholder wealth maximization goal on top of their mind. To operationalize this goal entails efficient decision making towards providing returns to the shareholders in the form of dividends, stock price appreciation that increase their wealth.

\section{Content analysis:}

The following tables reveal in which year each company reported that they were towards shareholder wealth maximization and further shows the medium they have adopted. 
Table 1: statements related to shareholder value disclosure in corporate governance reports

\begin{tabular}{|c|c|c|c|}
\hline Medium & Company Name & Year & Context \\
\hline \multirow[t]{22}{*}{$\begin{array}{l}\text { Corporate } \\
\text { Governance }\end{array}$} & Aarti Drugs Limited & 2010 to 2016 & $\begin{array}{l}\text { Good Corporate Governance helps enhancement of long term } \\
\text { shareholder value }\end{array}$ \\
\hline & Advik laboratories limited & $2015 \& 2016$ & $\begin{array}{l}\text { achieve business excellence and increasing long term shareholder } \\
\text { value }\end{array}$ \\
\hline & Amrutanjan Health Care & 2014 & $\begin{array}{l}\text { The Company believes that all its actions and operations must serve } \\
\text { the underlying goal of enhancing overall shareholder value on a } \\
\text { sustained basis. }\end{array}$ \\
\hline & Aurobindo Pharma & 2010 to 2016 & $\begin{array}{l}\text { 1. We as a team make effective use of our resources to create } \\
\text { shareholder value. } \\
\text { 2. We shall continue to look for ways to improve our visibility, grow } \\
\text { our revenues, improve our margins and generate shareholder value. } \\
\text { 3. striving to meet the expectations of the customers and creating } \\
\text { wealth for investors by delivering superior shareholder value. } \\
\text { 4. the Company belongs to all the stakeholders and the corporate } \\
\text { objective is to maximize shareholder value ethically and legally. }\end{array}$ \\
\hline & BDH Industries & 2012 to 2016 & $\begin{array}{l}\text { Good Corporate Governance helps enhancement of long term } \\
\text { shareholder value }\end{array}$ \\
\hline & Bharat Immunological & $2011 \& 2012$ & $\begin{array}{l}\text { The company constantly strives towards betterment of these aspects } \\
\text { and thereby perpetuate it into generating long term economic value } \\
\text { for its shareholders, customers, employees, other associated persons } \\
\text { and the society as a whole. }\end{array}$ \\
\hline & Cipla & 2010 to 2016 & $\begin{array}{l}\text { Its endeavour has always been to maximize the long term value to the } \\
\text { shareholders of the Company. }\end{array}$ \\
\hline & Coral Laboratories & 2015 & $\begin{array}{l}\text { The Company endeavors to improve upon aspects like transparency, } \\
\text { professionalism, accountability and fair disclosures, on an ongoing } \\
\text { basis and takes necessary steps towards growth and enhancing value } \\
\text { for its shareholders. }\end{array}$ \\
\hline & Denis Chem Lab & 2016 & $\begin{array}{l}\text { Effective Corporate Governance is the key element ensuring } \\
\text { investor's protection; providing finest work environment leading to } \\
\text { highest standards of management and maximization of everlasting } \\
\text { long -term values. }\end{array}$ \\
\hline & DIL Ltd & 2011 to 2016 & $\begin{array}{l}\text { The Company constantly strives towards betterment of aspects such } \\
\text { as transparency, professionalism and accountability and thereby } \\
\text { perpetuate it into generating long term economic value for its } \\
\text { shareholders, customers, employees, other associated persons and the } \\
\text { society as a whole. }\end{array}$ \\
\hline & $\begin{array}{l}\text { Dishman Pharmaceuticals } \\
\text { and Chemicals }\end{array}$ & 2010 to 2014 & $\begin{array}{l}\text { all its operations and actions must serve the underlying goal of } \\
\text { enhancing overall shareholder value, over a sustained period of time. } \\
\text { The Company continues to take necessary steps towards achieving } \\
\text { this goal. }\end{array}$ \\
\hline & Divis Laboratories & 2011 to 2016 & $\begin{array}{l}\text { It is a system of structuring, operating and controlling a company } \\
\text { with a view to achieve long term strategic goals to satisfy } \\
\text { shareholders, creditors, employees, customers and suppliers }\end{array}$ \\
\hline & Dr Reddys Laboratories & 2013 to 2015 & $\begin{array}{l}\text { Board go a long way in maintaining good corporate governance, } \\
\text { preserving shareholders' trust and maximizing long-term corporate } \\
\text { value. }\end{array}$ \\
\hline & FDC & 2010 to 2016 & $\begin{array}{l}\text { The board of directors of the Company are committed towards } \\
\text { discharging their fiduciary responsibility towards enhancing } \\
\text { shareholder's value and interest of all other stake-holders. }\end{array}$ \\
\hline & Gufic BioSciences & 2010 to 2014 & $\begin{array}{l}\text { operations and actions must serve the underlying goal of enhancing } \\
\text { overall shareholder value, over a sustained period of time. }\end{array}$ \\
\hline & $\begin{array}{l}\text { Jagsonpal } \\
\text { Pharmaceuticals }\end{array}$ & 2010 to 2016 & always striving for optimizing Shareholder' value. \\
\hline & Jubilant Life Sciences & $2010 \& 2011$ & $\begin{array}{l}\text { concern for society and environment and creation of extraordinary } \\
\text { value for shareholders }\end{array}$ \\
\hline & Kopran & 2014 to 2016 & ultimate objective of increasing long term shareholders value \\
\hline & Lincoln Pharmaceuticals & 2010 to 2016 & $\begin{array}{l}\text { The Company believes that good corporate governance leads to } \\
\text { corporate growth and long term gain in shareholders value. }\end{array}$ \\
\hline & Lupin & $2014 \& 2016$ & $\begin{array}{l}\text { The Company's legacies of professionalism, fairness and trusteeship } \\
\text { have been the guiding pillars which have enhanced shareholder value. }\end{array}$ \\
\hline & $\begin{array}{l}\text { Mangalam Drugs and } \\
\text { Organics }\end{array}$ & 2010 to 2016 & focused on maximizing shareholder value \\
\hline & Natco Pharma & $2014 \& 2016$ & $\begin{array}{l}\text { Board plays a fiduciary role in protecting the interests of the } \\
\text { stakeholders and at enhancing the shareholder value. }\end{array}$ \\
\hline
\end{tabular}




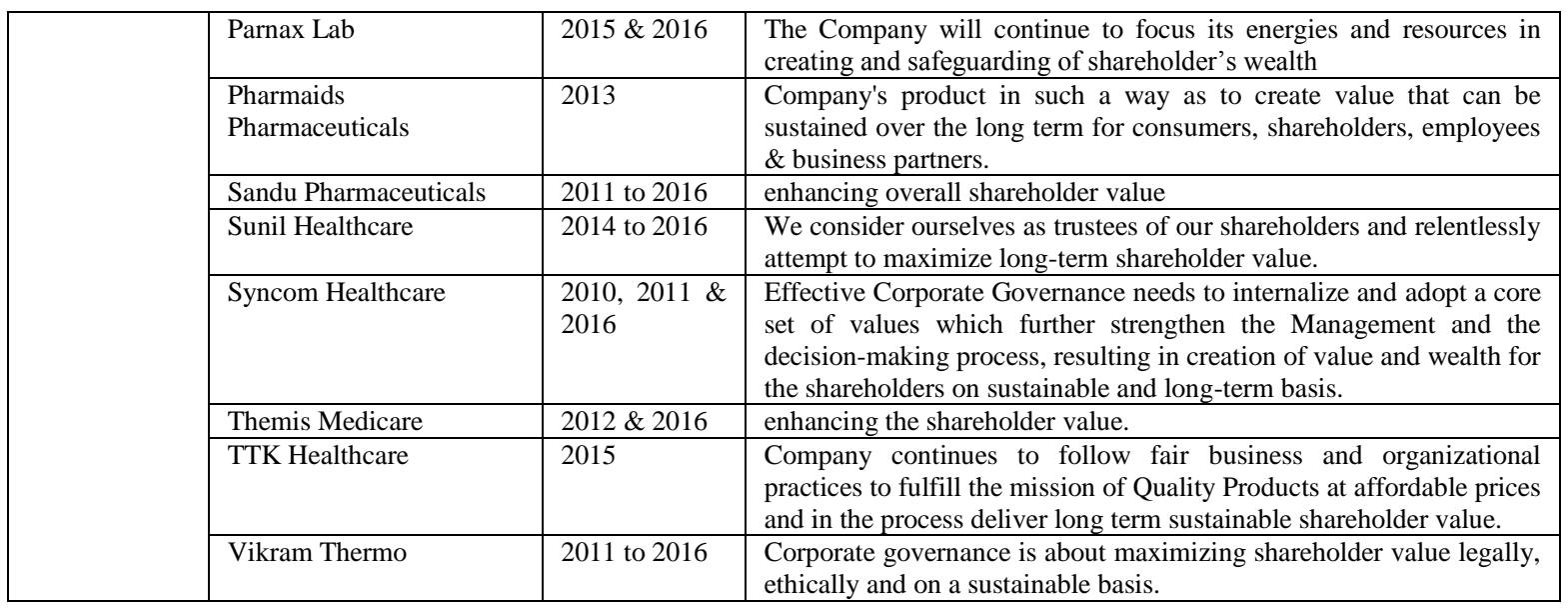

Table 2: statements related to shareholde value disclosure in Directors message

\begin{tabular}{|c|c|c|c|}
\hline Medium & Company Name & Year & Context \\
\hline \multirow[t]{10}{*}{$\begin{array}{l}\text { Directors } \\
\text { message }\end{array}$} & $\begin{array}{l}\text { Ahlcon Parenterals (India) } \\
\text { Limited }\end{array}$ & 2011 to 2015 & increase shareholder value - Dividend Payout \\
\hline & Alpa Laboratories Ltd & 2011 to 2015 & endeavored to optimize shareholder value \\
\hline & Amrutanjan Health Care & 2015 & $\begin{array}{l}\text { from growth to efficiency improvements that ultimately result in } \\
\text { shareholder value creation. }\end{array}$ \\
\hline & Beryl Drugs & 2010 to 2016 & $\begin{array}{l}\text { management is very hopeful to achieve better results in forthcoming } \\
\text { period and expects to achieve better financial results as per the } \\
\text { perception of the Shareholders of the Company. }\end{array}$ \\
\hline & Biofil Chemicals & 2010 to 2016 & $\begin{array}{l}\text { In order to enhance shareholder value and to sustain profitable } \\
\text { working, Board of Directors of the Company has entered into Tri } \\
\text { party agreement with HLL Lifecare Limited }\end{array}$ \\
\hline & $\begin{array}{l}\text { Dishman Pharmaceuticals } \\
\text { and Chemicals }\end{array}$ & 2015 & $\begin{array}{l}\text { As we collectively march ahead, I would like to assure you that we } \\
\text { will remain committed to building and increasing the value of our } \\
\text { shareholders' wealth in the coming years. }\end{array}$ \\
\hline & Ind-Swift & 2014 & $\begin{array}{l}\text { committed to make Ind Swift regain its position among top premium } \\
\text { Pharma companies of the country and a name to reckon with } \\
\text { maximizing shareholder's value and Corporate Governance. }\end{array}$ \\
\hline & Lupin & 2011 & ensuring sustainable shareholder returns. \\
\hline & Parnax Lab & 2012 & contributing higher value for shareholder \\
\hline & $\begin{array}{l}\text { Sun Pharmaceuticals } \\
\text { Industries }\end{array}$ & $2014 \& 2016$ & $\begin{array}{l}\text { Businesses will need to be more innovative as well highly cost } \\
\text { competitive to ensure long-term sustainable value for shareholders. }\end{array}$ \\
\hline
\end{tabular}

Table 3: statements related to shareholde value disclosure in Chairmans message

\begin{tabular}{|l|l|l|l|}
\hline Medium & Company Name & Year & Context \\
\hline message & Cadila Healthcare & $2014 \& 2016$ & $\begin{array}{l}\text { we will continue to drive stronger growth and enhance shareholder } \\
\text { value. }\end{array}$ \\
\cline { 2 - 4 } & Dr Reddys Laboratories & $2013 \& 2016$ & $\begin{array}{l}\text { We have also initiated a share buyback to leverage strong cashfl ows, } \\
\text { strengthen } \\
\text { our balance sheet and deliver value to you, our shareholders. }\end{array}$ \\
\cline { 2 - 4 } & Gufic BioSciences & 2011 & $\begin{array}{l}\text { The Board promises that the Company shall achieve laid down targets } \\
\text { for the future which in turn will yield higher returns to shareholders in } \\
\text { form of increased share value and higher rate of dividend. }\end{array}$ \\
\cline { 2 - 5 } & Hikal & $2014 \& 2016$ & Our focus remains on creating shareholder value \\
\cline { 2 - 5 } & J B Chemicals & 2014 to 2016 & to create wealth and value for our shareholders. \\
\cline { 2 - 5 } & Jubilant Life Sciences & 2012 to 2015 & $\begin{array}{l}\text { aim to continue our efforts to constantly create value for our } \\
\text { shareholders by integrating sustainability in all our operational } \\
\text { parameters. }\end{array}$ \\
\cline { 2 - 5 } & Natco Pharma & 2015 & $\begin{array}{l}\text { will continue to grow our base business, enabling us to sustain } \\
\text { shareholder value growth. }\end{array}$ \\
\cline { 2 - 4 } & Piramal Enterprises & 2011 to 2016 & $\begin{array}{l}\text { This exciting journey has enabled us to deliver an annualised } \\
\text { shareholder return of 28.5\% over last twenty-eight years, a track record } \\
\text { achieved by few companies in India. }\end{array}$ \\
\hline
\end{tabular}


Table 4: statements related to shareholde value disclosure in separate section

\begin{tabular}{|l|l|l|l|}
\hline Medium & Company Name & Year & Context \\
\hline Separate Section & Natco Pharma & 2015 & $\begin{array}{l}\text { Natco possesses a credible record of strengthening shareholder value in } \\
\text { good and bad markets through astute business management, strategic } \\
\text { long-term initiatives, profit sharing and governance. }\end{array}$ \\
\cline { 2 - 4 } & Piramal Enterprises & 2016 & $\begin{array}{l}\text { The Company has delivered a strong track record of generating } \\
\text { superior shareholder returns over the last three decades. }\end{array}$ \\
\cline { 2 - 4 } & $\begin{array}{l}\text { Syncom } \\
\text { Formulations }\end{array}$ & $2015 \& 2016$ & $\begin{array}{l}\text { committed to creating value for its other stake holders by ensuring that } \\
\text { its corporate actions positively impact the socio-economic and } \\
\text { environmental dimensions and contribute to sustainable growth and } \\
\text { development. }\end{array}$ \\
\hline
\end{tabular}

Table 5: statements related to shareholde value disclosure in financial highlights

\begin{tabular}{|l|l|l|l|}
\hline Medium & Company Name & Year & Context \\
\hline $\begin{array}{l}\text { Financial } \\
\text { Highlights }\end{array}$ & Gufic BioSciences & 2016 & $\begin{array}{l}\text { Our approach and commitment towards business and sustainable living } \\
\text { has created astrong business for shareholders with profitable long term } \\
\text { growth. }\end{array}$ \\
\cline { 2 - 4 } & Ind-Swift & 2010 & $\begin{array}{l}\text { Reserves represent the shareholders wealth and as it are ploughed back } \\
\text { in the business, is the most cost effective fund for the company. }\end{array}$ \\
\cline { 2 - 4 } & Lupin & $2011 \& 2016$ & $\begin{array}{l}\text { Lupin's sustained growth performace and focus on operational } \\
\text { excellence has resulted in outstanding shareholders return of over 15 } \\
\text { times in the last 10 years }\end{array}$ \\
\cline { 2 - 4 } & Medi-Caps & 2013 to 2016 & $\begin{array}{l}\text { further business plans to maximize the worth of the company and its } \\
\text { shareholders }\end{array}$ \\
\cline { 2 - 4 } & Morepen Laboratories & 2013 to 2016 & maximization of Shareholders' value/wealth \\
\cline { 2 - 4 } & Venus Remedies & $2012 \& 2013$ & $\begin{array}{l}\text { Despite a dismal business environment, the Company's improved } \\
\text { performance strengthened its Balance Sheet and its ability to grow } \\
\text { shareholder value. }\end{array}$ \\
\hline
\end{tabular}

Table 6: statements related to shareholde value disclosure in Other reports

\begin{tabular}{|l|l|l|l|}
\hline Medium & Company Name & Year & Context \\
\hline Other & Lupin & 2015 & $\begin{array}{l}\text { Delivering outstanding shareholder returns and creating incremental } \\
\text { value for shareholders }\end{array}$ \\
\hline Outlook & $\begin{array}{l}\text { Sun Pharmaceuticals } \\
\text { Industries }\end{array}$ & 2016 & $\begin{array}{l}\text { Sun Pharma has embarked on various initiatives globally to drive } \\
\text { future growth and profitability and to enhance longterm shareholder } \\
\text { value. }\end{array}$ \\
\hline R\&D & Lupin & 2011 & $\begin{array}{l}\text { We must create a genuinely strong intellectual property that hedges our } \\
\text { investments and ensures shareholder value. }\end{array}$ \\
\hline Responsibility report & Cadila Healthcare & 2013 & $\begin{array}{l}\text { Achievements have strengthened the Company's belief that it is } \\
\text { possible to create and enhance shareholder value by being growth } \\
\text { oriented, making research and innovation a cornerstone and creating } \\
\text { healthier communities globally. }\end{array}$ \\
\cline { 2 - 4 } & Dr Reddys Laboratories & 2013 & $\begin{array}{l}\text { Our consistent efforts to integrate sustainability into all our activities } \\
\text { right from discovery to dispatch are helping us add value across } \\
\text { environmental, social, cultural and economic bottom lines as well as } \\
\text { creates long-term consumer, shareholder and employee value. }\end{array}$ \\
\hline
\end{tabular}

\section{Shareholder value disclosure in Corporate governance reports}

Most of the companies in the sample have mentioned that they are towards enhancing shareholder value in corporate governance reports and business philosophy. They also believed that good corporate governance helps them to achieve this corporate goal to sustain in the competitive markets like India. Every company constantly strives towards the goal of enhancing firm's value, thereby increasing the long term shareholder value. The goal enabling them to improve upon aspects like transparency, professionalism, accountability and fair disclosures over a period of time to build trust in shareholders. These companies are promisingly following the corporate governance practices in the sample period and every organization is looking forward to build a long term relationship with the shareholders to attract the long term capital.

\section{Shareholder value disclosure in Chairmen and Directors message}

In order to enhance shareholder value, the board of directors of the sample companies mentioned in table 2 expects to achieve better financial results as per the perception of shareholders of the company and most of them assure that the commitment and strategic decisions by them will show the road towards achieving laid down targets over a period of time that in turn will yield higher value to shareholders in the form of higher dividends and stock 
Shareholder Value Disclosure Practices In India: A Content Analysis

price appreciation. Chairman of Piramal enterprises mentioned in the 2016 " this exciting journey has enabled us to deliver an annualized shareholder return of $28.5 \%$ over last twenty eight years, a track record achieved by a few companies in India." This shows every director or chairman striving for better results for shareholders to sustain in the market.

\section{Shareholder value disclosure in financial highlights}

Most of the companies use financial highlights reports to showcase their financial performance over a period of time or how far they are w.r.t to the previous year. Where as the companies in table 3 used financial highlights reports to report that they have achieved shareholder wealth maximization along with the financial highlights of the financial year. One of the market leaders of the pharmaceutical industry in India mentioned that Lupin's sustained growth performance and focus on operational excellence has resulted in outstanding shareholder return of over 15 times in the last 10 years."

\section{Shareholder value disclosure in separate section}

The organizations mentioned in table 4 have mentioned in 2015 and 2016 annual reports that they are towards enhancement of shareholder in the separate section of annual reports along with the regular disclosure practices. Organizations are trying to grab the special interest of the shareholder towards it and building a top position on the top of his mind. So that when he want to invest his hard earned money in the capital markets, these companies will be the top priority for him.

\section{Shareholder value disclosure in other reports}

Organizations in table 5 have used other reports such as CFO's letter, Outlook and research \& development reports. The reports show that they were towards enhnacing shareholder value. They mentioned the research activities and intellectual property that are are undertaking will drive shareholder value.

\section{Shareholder value disclosure in vision and mission statements}

Further, we explored whether vision and mission statements of organizations present in this sample contain any relevant information about enhancing shareholder value. The study found non of the organization in the sample mentioned were towards the enhancing shareholder value. They have mentioned the organization's purpose and its future directions about the products, technology, customers and community. This may be because of the nature of the pharmaceutical industry in India, i.e., a fragmented industry and developing market with high competition in all product segments. Every organization in the industry will spend higher capital in research and development in the production of high quality generic medicines. This enables them in achieving a higher market share.

The research investigating relationship between mission, vision statements and shareholder value is rare and its findings in most cases not very conclusive. We need to introduce other intervening variables to fully understand the relation.

\section{Conclusion}

Since then, all kinds of companies have been publicly proclaiming their commitment to increasing longterm value for their shareholders. One look at the statements of directors or the chairman and annual reports can confirm this. The aim of publicly listed companies has always been to increase the value of shareholders' investment. It is believed that with better corporate with good governance, listed firms can reduce agency costs, become more competitive in global markets, fulfill their social responsibilities and create long term shareholder value. non of the organization in the sample mentioned they were towards the enhancing shareholder value. They have mentioned the organization's purpose and its future directions about the products, technology, customers and community as the pharmaceutical industry technology and product oriented.

\section{Limitations and Scope for future study}

In the present study, annual reports, mission, and vision statements were assessed in regard to organizational commitment towards the modern organizations goal i.e., shareholder wealth maximization and a theoretical model have been developed with certain prepositions. Further the model can be validated with the qualitative and quantitative data obtained from the managers. The annual reports, mission and vision statements were examined only focusing on the good statements presented to them and the content of financial reports was ignored. More conclusive results can be brought by considering the other financial results. 


\section{Bibilography}

[1]. Alhazaimeh, A., Palaniappan, R., \& Almsafir, M. (2014). The Impact of Corporate Governance and Ownership Structure on Voluntary Disclosure in Annual Reports among Listed Jordanian Companies. Procedia - Social and Behavioral Sciences, 129(Winter), 341-348. https://doi.org/10.1016/j.sbspro.2014.03.686

[2]. Bart, C. K., \& Hupfer, M. (2004). Mission statements in Canadian hospitals. Journal of Health Organization and Management, 18(2-3), 92-110. https://doi.org/10.1108/14777260410538889

[3]. Beck, V., \& Britzelmaier, B. (2013). A Value-Based Management Perspective for the Automotive Industry. World Review of Entrepreneurship, Management and Sustainable Development, 9(2), 136-151. https://doi.org/10.1504/WREMSD.2013.052355

[4]. De Beer, E. (2014). Creating value through communication. Public Relations Review, 40(2), 136-143. https://doi.org/10.1016/j.pubrev.2014.02.024

[5]. Dermol, V. (2012). Relationship between mission statement and company performance. Management Knowledge and Learning International Conference 2012, 891-899. https://doi.org/10.2478/v10316-012-0022-9

[6]. Dockery, E., \& Herbert, W. E. (2000). Corporate Governance, Managerial Strategies and Shareholder Wealth Maximisation : A Study of Large European Companies, 26(9).

[7]. Groth, J. C. (1989). CORPORATE COMMUNICATIONS AND FIRM VALUE. The British Accounting Review, 21(1), $106-107$. https://doi.org/10.1016/0890-8389(89)90087-5

[8]. Ho, V. H. (2010). "Enlightened Shareholder Value": Corporate Governance Beyond the Shareholder-Stakeholder Divide. Journal of Corporation Law, 36(1), 59-112. Retrieved from http://search.ebscohost.com/login.aspx?direct=true \&db=bth\&AN=56504054\&site=bsilive\&scope $=$ site

[9]. Hooghiemstra, R. (2010). Letters to the shareholders: A content analysis comparison of letters written by CEOs in the United States and Japan. International Journal of Accounting, 45(3), 275-300. https://doi.org/10.1016/j.intacc.2010.06.006

[10]. Kaur, M., \& Narang, S. (2010). EVA Disclosures in the Annual Reports of Indian Companies: An Empirical Study. Global Business Review, 11(3), 395-420. https://doi.org/10.1177/097215091001100306

[11]. Leszczynska, A. (2012). Towards shareholders' value: an analysis of sustainability reports. Industrial Management \& Data Systems, 112(5-6), 911-928. https://doi.org/10.1108/02635571211238518

[12]. Lichtenstein, S., \& Dade, P. (2007). The shareholder value chain: Values, vision and shareholder value creation. Journal of General Management, 33(1), 15-31.

[13]. Loderer, C., Roth, L., Waelchli, U., \& Joerg, P. (2010). Shareholder Value : Principles , Declarations , and Actions, (2004), 5-32.

[14]. Macedo, I. M. (n.d.). Exploring the Link between Mission Statements and Organisational Performance in Non-profit Health Care Organisations Exploring the Link between Mission Statements and Organisational Performance in Non-profit Health Care Organisations, 2010.

[15]. Nobanee, H., \& Ellili, N. (2015). Corporate sustainability disclosure in annual reports: Evidence from UAE banks: Islamic versus conventional. Renewable and Sustainable Energy Reviews, 55, 1336-1341. https://doi.org/10.1016/j.rser.2015.07.084

[16]. Omran, M., Atrill, P., \& Pointon, J. (2002). Shareholders versus stakeholders: corporate mission statements and investor returns. Business Ethics: A European Review, 11(4), 318-326. https://doi.org/10.1111/1467-8608.00291

[17]. Rappaport, A. (2006). 10 Ways to Create Shareholder Value. Harvard Business Review, 84(9), 66-77. Retrieved from http://web.a.ebscohost.com.libproxy.aalto.fi/ehost/detail/detail?sid=2ebeed04-48c4-4a9d-ad70-

a89619d4e727@ sessionmgr4003\&vid=0\&hid=4109\&bdata=JnNpdGU9ZWhvc3QtbGl2ZQ==\#db=bth\&AN=21882958 